\title{
TEACHING GRAMMAR TO YOUNG LEARNERS USING COMIC STRIPS AND GTM AND THE IMPACT ON THEIR SPEAKING SKILLS
}

\author{
E. Suseno', S.Setiawan ${ }^{2}$ \\ ${ }^{12}$ English Language Education, Post Graduate Program, Universitas Negeri Surabaya, Surabaya \\ e-mail: edysuseno4@gmail.com
}

\begin{abstract}
Practicing speaking in EFL to the young learners especially to the fifth graders is challenging. They do not have enough vocabulary in their repertoire so that it is often difficult for them express their ideas in the foreign language. They also could not construct appropriate sentences to reflect how well they have learnt so far. For this reason, the implementation of the grammar-translation method may be needed to help them focus on grammatical aspect of the foreign language to enhance their perspective in learning grammar and reading comprehension. Moreover, the use of books, podcast, comic strips and electronic dictionary could support the process of treatment. By implementing this kind of method, the students could enhance their speaking skills. They also have the opportunity to experience with language use and support their progress in speaking. This kind of development could be seen from the result of the pre-test and post-test. The progress of development was significant which reflect the positive impact of comic strips and GTM on children speaking skills
\end{abstract}

\section{Keywords: Comic Strips; Grammar-Translation Method; Speaking Skills}

\section{INTRODUCTION}

Teaching English as a foreign language for young learners does not only need passion on the part of the teacher, but also outstanding pedagogical skills that meet the characteristics of young learners. It is a common knowledge that young learners have a preference of learning by playing. They want to have some joyful learning through singing, physical activities and appropriate materials and instruction. By recognizing the students' needs, the teacher could adopt appropriate teaching methods and strategies for fun and effective teaching-learning process (Setyaningsih, 2007).

Copland (2014) points out that young learners are the children aged 3 to 12 years old. At this range of age, they usually attend a play group, kindergarten or elementary schools. They need role model to learn how to speak in English. In this point of view, the teacher should provide himself to be the one to imitate. The young learners also love to study in a group. They could exchange the knowledge among friends. Indeed, they love to do group activities and learn to speak through group interaction. It is the teachers' creativity that will boost the students learning. For example, the teachers need to make use of the children background knowledge and relate that to a class topic for speaking practice.

Comic is a kind of media that amuse readers by presenting some character pictures with some conversation scripts. People in any age love to read comics. The young learners like to read comics with heroic topic. The characters of Naruto, Shin Chan, and many others invite the young learners to read them. This favorable topic makes the young learner become curious. They often bring such kind of comics anywhere to read (Huang, 2008).

Putting grammatical material into a comic strip could be expected to bring a positive impact of young children learning of English. Teacher could use the favorable characters to talk about the implementation of the grammar rules. By doing so, the students will be comfortable to enjoy the flow of the explanation. Comic strips, however, is fun as well. It could invite the readers into the flow. The readers tend to follow the story from one page to the other. Implementing comic strips in learning grammar could bring the students into the real setting of speaking because it involves the enrolment of the activity (Derrick, 2008).

To enhance speaking competence, the students need to know how to construct sentences. By knowing the rules of constructing sentences or grammar, they are able to Jurnal Pendidikan Bahasa Inggris Indonesia | 19 
deliver their understandable intention (Sysoyev, 1999). There are some ways to learn grammar. One of them is the grammar-translation method or GTM. By adopting this kind of method, the teacher discusses the grammar rules bilingually. It eases the students to understand the grammar rules and adapt them to speaking (Aqel, 2013).

EFL young learners tend to learn by copying from the people they interact with. Their learning was initiated by providing the context for communication and meaning-making. (Moon, 2000). Most of young learners are eager learners to learn something that interests them. By considering this kind of characteristic, teachers should elicit and persuade them to get involved in the teaching-learning process (Brown, 2001). Providing various activities is very important to maintain their interest in classroom learning (Harmer, 2001). To gain a successful result in teaching the EFL young students, the teachers need to expose the second language input very often by giving some authentic resources and opportunities to practice (Saville-Troike, 2006).

To gain success in communicating, meaning-making, and fluency, students need a good model. In the context of Teaching English to Young Learners (TEYL), the role of the teachers as the model is very important. In addition to become a model, the teacher should also provide learning experiences and learning media that are appropriate for young learners. The form of media should be able to motivate them to get involved in the teachinglearning process. To lead the students to be able to practice speaking, the authentic material to support the use of media is very useful. Using media and template need to be developed in teaching English to EFL young learners to gain the optimum result.

Rababa'h (2005) stated that young EFL learners get difficulties in expressing their ideas in the form of utterances. They have problems in delivering their intention and to response to questions. They do not know what to say when they want to tell others about their thought. They also get a problem to understand the words when somebody else describe something to them. It seems that they have insufficient vocabulary that results in limited ability in constructing sentences, communicate orally and listen to spoken language.

The use of comic strips to teach English to young learners could be expected to enhance students' interest to learn a new language. The students will experience a fun learning in grammar, vocabulary, and speaking (Prawerti, 2015). Moreover, the insertion of grammar by using GTM, the students can understand how to construct sentences properly. This kind of ability can lead the students to produce meaningful utterances in practicing speaking (Kaharuddin, 2018).

The purpose of this paper is to describe how effective comics strips and GTM to enhance young learners' speaking competence. The result of the findings can be used by the teachers to enrich their reference to hold the classroom teaching-learning process. It is also inspiring other researchers to complete other research.

\section{RESEARCH METHOD}

The fifth graders from a public elementary school were involved in this research. They still get difficulty to express their ideas. The number of students joining this activity was 23 comprises 13 females and 10 males. Before the treatment was getting started, they did a pretest. It is the way to see their level of competence in speaking. For joining this treatment, the students got the books as guidance to learn. This book discussing grammar using GTM, providing some URLs about reading, listening, and speaking. The application of an electronic dictionary was installed on the students' cellphone before starting the activity. They could use this dictionary to support their learning process to gain a desirable understanding. In each period of treatment has the same pattern of learning procedure as discussing grammar, and adapting comic strips to implement the grammar discussed into speaking practice. Materials for speaking were also collected from some URLs contain materials for reading and speaking to develop the students' vocabulary and speaking skills. 
The sample of GTM and comic strips are shown in the following caption.

1. Ini adalah Adit. Ini adalah kaos oblongnya. Ini adalah miliknya=

2. Itu adalah Hadi. Itu adalah celana pendeknya. Itu adalah miliknya=

3. Ini adalah Ali. Itu adalah kaos lengan panjangnya. Itu adalah miliknya=

2. Hers=miliknya (wanita). Kata hers harus berdiri sendiri. Tidak boleh diikuti kata benda bila berarti miliknya.

Contoh

Itu adalah Diana. Itu adalah rumahnya. Itu adalah miliknya= That is Diana. It is her house. It is hers.

A. Latihan 5

1. Itu adalah Tety. Itu adalah jaketmya. Itu adalah miliknya=

2. Ini adalah Rina. Itu adalah kaos polonya. Itu adalah miliknya=

3. Itu adalah Susi. Ini adalah bajunya. Ini adalah miliknya=

4. Itu adalah Agung. Itu adalah sepatumya. Itu adalah miliknya=

3. Its = miliknya (binatang atau benda). Kata its harus berdiri sendiri. Tidak boleh diikuti kata benda bila berarti miliknya. Contoh

Itu adalah seekor anjing. Itu adalah kandangnya. Itu adalah miliknya= That is a dog. It is its cage. It is its

A. Latihan 6

1. Itu adalah seekor kuda. Ini adalah makanannya. Ini adalah miliknya=

pg. 74

2. Ini adalah sebuah sepeda. Ini adalah rodanya. Ini adalah miliknya=

3. Itu adalah seekor ayam. Ini ada lah telornya. Ini adalah miliknya=

4. Ini adalah Rita. Itu adalah kaos lengan panjangnya. Itu adalah miliknya=

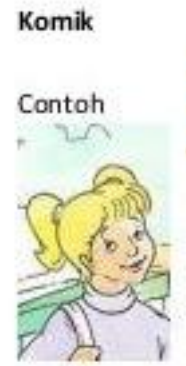

(1a)
That is Sam. That is his t-shirt. It is his

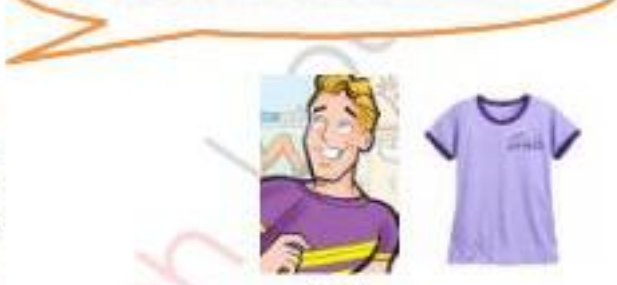

Sam

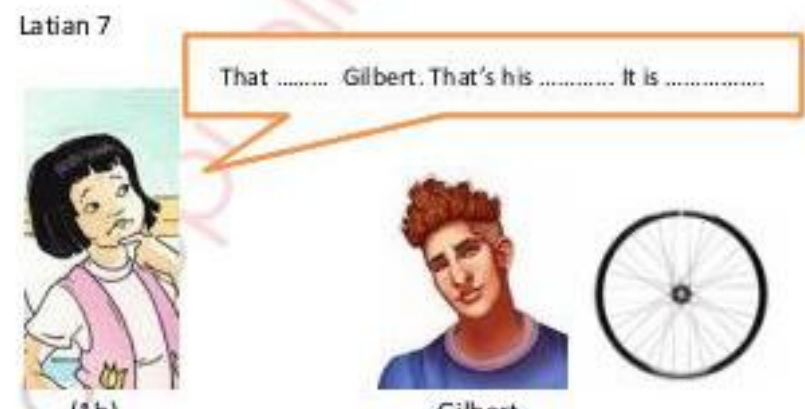

(1b)

Gilbert

pg. 75 
The following caption is the sampel of reading and conversation materials.

Reading (klik url reading yang tersedia. Dengarkan dan tirukan)

1. Going to the Zoo

https://www.eslfast.com/kidsenglish/ke/ke001.htm

She goes to the zoo. She sees a lion. The lion roars. She sees an elephant. The elephant has a long trunk. She sees a turtle. The turtle is slow. She sees a rabbit. The rabbit has soft fur. She sees a gorilla. The gorilla is eating a banana.

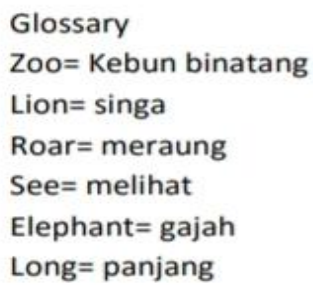

Terjemahkanlah bacaan diatas!

Conversation (klik url conversation yang tersedia. Dengarkan dan tirukan dengan berpasangan)

1. I Live in Pasadena

https://www.eslfast.com/easydialogs/ec/dailylife001.htm
A : Where do you live?
B : I live in Pasadena.
A : Where is Pasadena?
B : It's in California.
A : Is it in northern California?
B : No. It's in southern California.
A : Is Pasadena a big city?
B : It's pretty big.
A : How big is "pretty big"?
B : It has about 140,000 people.
A : How big is Los Angeles?
B : It has about 3 million people.

Terjemahan
A : Where do you live? = Dimana kamu tinggal?
B : I live in Pasadena. = saya tinggal di Pasadena.
A : Where is Pasadena? = Dimana Pasadena?
B : It's in California. = Dia di California.
A : Is it in northern California? = apakah di sebelah utara California?
B : No. It's in southern California. = Tidak. Dia di sebelah selatan California.
A : Is Pasadena a big city? = Apakah Pasadena sebuah kota yang besar?

pg. 214

There were 18 opportunities for treatment. Each opportunity takes 90 minutes. At the end of the treatments, the students joined the post-test. A rubric was used to assess the students' speaking competence in the pre-test and post-test. The data found in the pre-test and post-test were analyzed to meet the result and conclusion. 


\section{FINDINGS AND DISCUSSION \\ Findings}

There were two major activities in conducting this research. They are before and after treatment. Before doing the treatment, some preparations were upheld like choosing the classroom, confirming the schedule, distributing the books, and the availability of internet access. The stages of the treatment can be seen in the following.

\section{Before treatment}

To see the level of the students' competence in speaking before joining the treatment, the students need to do a pre-test. To satisfy the assessment, a rubric was established. It is about the criteria to measure the level of capability of the students in speaking. The form of the rubric used in this research can be seen as follows.

\section{Rubric}

Table 1. Choosing Words

\begin{tabular}{lll}
\hline No & Range of Description Scores & Description \\
\hline 1 & 50-59: Very bad & Almost cannot utter a single word. \\
2 & 60-69: Bad & Saying two or more words intermittently. \\
3 & 70-79: Average & Conveying the ideas intermittently. \\
4 & 80-89: Good & Expressing an understandable opinion. \\
5 & $90-100:$ Very Good & Delivering the ideas properly both in choosing \\
& & and pronouncing the words. \\
\hline
\end{tabular}

Table 2. Adapting Intonation

\begin{tabular}{lll}
\hline No & Range of Description Scores & Description \\
\hline 1 & 50-59: Very bad & $\begin{array}{l}\text { The intonation is flat. } \\
\text { Adapting the intonation but It does not reflect } \\
\text { the intention. }\end{array}$ \\
3 & 70-79: Average & $\begin{array}{l}\text { The proper intonation is adopting in some } \\
\text { occasions. }\end{array}$ \\
4 & 80-89: Good & $\begin{array}{l}\text { Putting the right intonation on the proper place } \\
\text { but sometimes falling into the flat. } \\
\text { Saying the tone of the words smoothly in } \\
\text { accordance with the intention. }\end{array}$ \\
\hline
\end{tabular}

Table 3. Getting The Fluency

\begin{tabular}{|c|c|c|}
\hline No & Range of Description Scores & Description \\
\hline 1 & 50-59: Very bad & $\begin{array}{l}\text { Delivering ideas with a few words or phrases } \\
\text { in a long pause. }\end{array}$ \\
\hline 2 & 60-69: Bad & $\begin{array}{l}\text { Delivering ideas with improper sentence } \\
\text { building. }\end{array}$ \\
\hline 3 & 70-79: Average & Delivering ideas with proper sentence building. \\
\hline 4 & 80-89: Good & $\begin{array}{l}\text { Delivering ideas with proper sentence building, } \\
\text { choosing words, and intonation adaptation. }\end{array}$ \\
\hline 5 & 90-100: Very Good & $\begin{array}{l}\text { Delivering ideas with the proper sentence } \\
\text { building, pause placement, choosing words, } \\
\text { speaking speed, and intonation adaptation. }\end{array}$ \\
\hline
\end{tabular}

Implementing a test to assess the students' competence in speaking, to determine how to start the treatment. The form of the questions are interview and describing a picture. It is a way to assess the students' ability in vocabulary building, grammar usage, intonation, and fluency. This kind of question is used both for pre-test and post-test. The form of the questions could be seen as follow: 


\section{A. Pre-test dan Post-test}

1. Answer the questions below! (Interview)
a. Tell me about your family!
b. Tell me about your close friend!
c. Tell me about some food you love to eat!
d. Tell me about your favorite subject! Why?
e. Tell me about something you love to do! Why?
f. Tell me about your favorite teacher! Why?
g. Tell me about your school!
h. Tell me about the animal you do not like! Why?
i. Tell me about your favorite color! Why?
j. Tell me about your house!

2. Describe the picture below as far as you can!

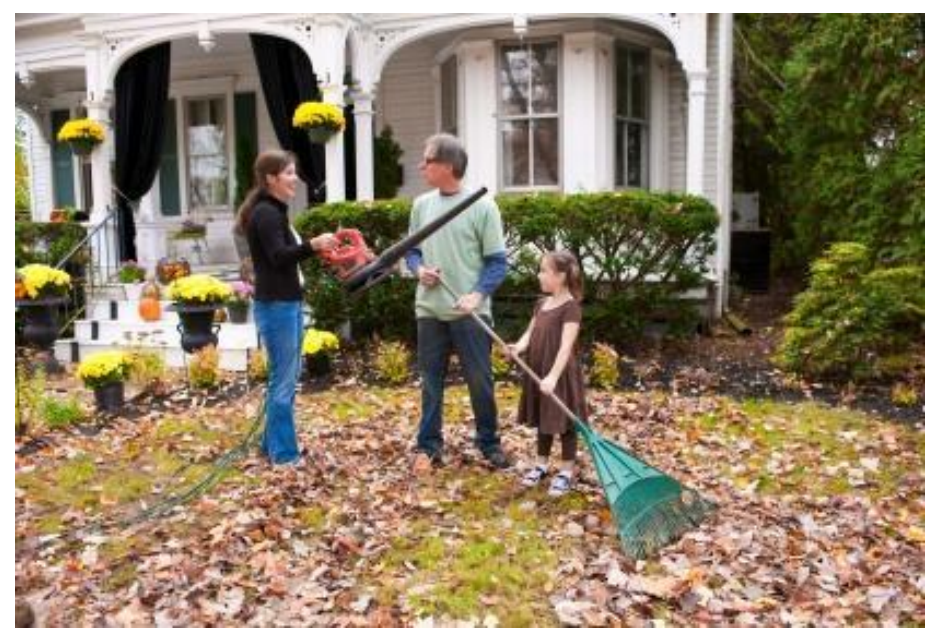

Preparing to distribute the books after completing the creation of rubric, pre-test, and post-test. That kind of book was written Suseno, It has registered a number of ISBN and copyright. The title of this book is "BelajarBahasa Inggris dengan Metode Komik". All the material in the book was adapted to elementary school students. The cover of this book could be seen below.

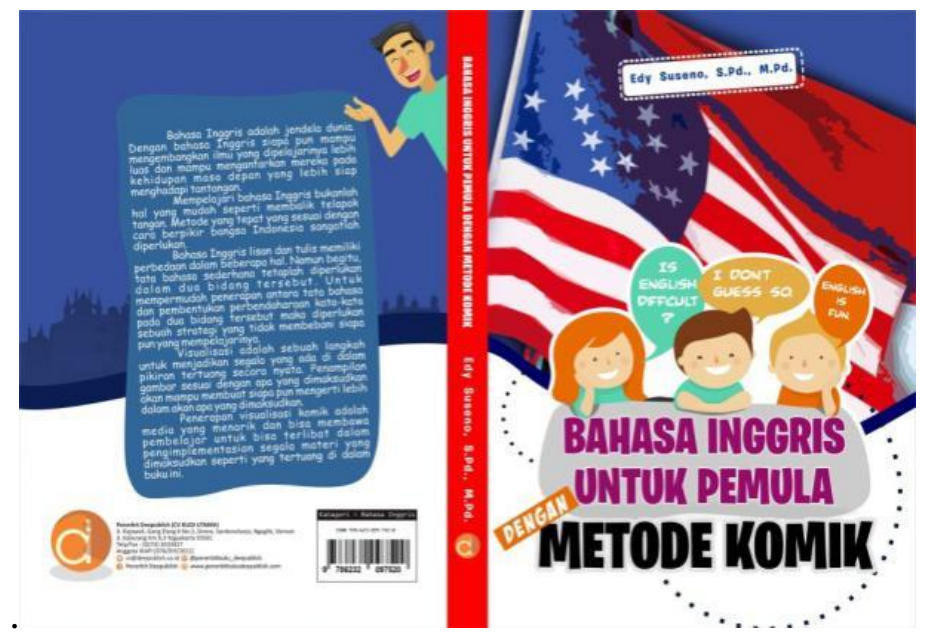

Figure 1. The cover of the book

After completing the preparation of the treatment, the action started by visiting the school where the treatment will be conducted to ask a permit to do the research. After some time of discussion, the principle agreed to uphold research in his school. The agreement was about forming a class of research, a pre-test, a post-test, and a schedule of treatment. Conducting a pre-test as the first step was completed to start the treatment. The result of the Jurnal Pendidikan Bahasa Inggris Indonesia | 24 
pre-test could be seen as follow.

Table 4. Pre-test Scores

\begin{tabular}{lllll}
\hline No & Fluency & Intonation & Vocabulary & Average \\
\hline 1 & 53 & 54 & 52 & 53 \\
2 & 52 & 51 & 53 & 52 \\
3 & 51 & 52 & 51 & 51,33333 \\
4 & 55 & 54 & 52 & 53,66667 \\
5 & 54 & 53 & 55 & 54 \\
6 & 56 & 55 & 53 & 54,66667 \\
7 & 57 & 58 & 59 & 58 \\
8 & 56 & 55 & 57 & 56 \\
9 & 54 & 53 & 55 & 54 \\
10 & 56 & 55 & 56 & 55,66667 \\
11 & 57 & 58 & 59 & 58 \\
12 & 53 & 52 & 54 & 53 \\
13 & 55 & 54 & 55 & 54,66667 \\
14 & 52 & 51 & 52 & 51,66667 \\
15 & 51 & 52 & 51 & 51,33333 \\
16 & 50 & 51 & 52 & 51 \\
17 & 56 & 55 & 57 & 56 \\
18 & 54 & 52 & 53 & 53 \\
19 & 55 & 56 & 58 & 56,33333 \\
20 & 53 & 54 & 53 & 53,33333 \\
21 & 52 & 53 & 52 & 52,33333 \\
22 & 55 & 55 & 56 & 55,33333 \\
23 & 58 & 56 & 57 & 57 \\
Average & 54,13043 & 53,86957 & 54,43478 & 5,14493 \\
\hline
\end{tabular}

From the score list above, it could be seen that the lowest score is 50 and the highest one is 59. Most of the students got 54 in their speaking assessment. Based on the rubric, it is categorized as very bad. It seems that the students' background knowledge in speaking is very low. Of 23 students, there are only two students got 58 in their average scores. In this condition, all students in that class need to improve their speaking skills to make their utterances understandable.

\section{During treatment}

In the first treatment, the teacher distributed the books. He explained the purpose of the treatment. He made sure that each student had his own cellphone with the headset and the internet access was available in the classroom. He asked the students to install an electronic dictionary in their gadgets like guided in the book. Nobody failed to get that kind of application on their own. The teacher also said that every student can use such a dictionary whenever he wants to know the meaning and the pronunciation of the words. Harmer (2007) said that Vocabulary building is very important for the students to enhance their speaking skills. Furthermore, to conduct the assessment and delivering the information the teacher asked the students to join the WhatsApp.

After the installation of the dictionary was successful, the teacher started to discuss the grammar point by implementing GTM. The students did all the grammar exercises in bilingual. After a period of time, the teacher checked the students' work to ensure that their works were correct. When the teacher found some errors in the students' works, he guided them to correct them. Finishing the grammar exercises took time because the teacher needed to check them one by one to ensure that the students understand the 
usage of the material discussed.

To make the grammar rules to be applicable to speaking, the teacher asked each student to check the pronunciation of each sentence in the exercises to their electronic dictionary. To avoid the noise disturbance, the teacher asked the students to put their headsets on. After checking the pronunciation, the teacher assigned them to read and record them through the WhatsApp group application. The teacher checked each work to ensure that the students' pronunciation is proper. He would give some corrections toward the mispronunciation by asking them to check it to their electronic dictionary and rerecord it until they got the proper pronunciation. Richards, et al. (1985) stated that pronunciation is very important in speaking. It determines the level of clarity uttered by the speakers for the listeners.

To implement the grammar usage into speaking, the teacher asked the students to complete the comic strip exercises. They used their dictionary to check the pronunciation of the sentences. If the exercise was a monologue, the students recorded it to the Whatsapp group by themselves. But, if it was dialogue, the students needed to practice it with their partners and record it to the Whatsapp group to assess. The students need to be able to adapt grammatical points into conversation. Heaton (2004) said that the implementation of grammar rules into speaking practice is very important to make the utterances to be understandable.

Nevertheless, the students needed to develop their grammatical knowledge. To satisfy this kind of skill, the teacher asked the students to click the URL given on their cellphones. By clicking that kind of URL, the students could get the text and recording. Through doing such a thing, the teacher asked the students to circle the grammar points mentioned in the previous discussion. After completing their works, the students were invited by the teacher to discuss their noticing works. It is inline with Richards and Renandya's (2005) idea. He said that the teacher needs to design and administer the classroom activity into a communicative atmosphere.

To build the students' pronunciation and listening skills, the teacher asked the students to click the play button on the recording thumbnail attached to the reading page. The teacher always reminded them to put their headset on while turning the volume on to avoid the noise disturbance. After finishing listening to the recording, the teacher assigned them to read the text and record it to the WhatsApp group to assess the properness of the pronunciation. The teacher would ask for rechecking their pronunciation in their electronic dictionary for the mispronunciation and rerecord it to reassess. Pronunciation and listening are an important part of the conversation. It enables the parties to exchange information (Brown, 2001).

The URLs are containing two types of materials reading text and conversation scripts. By learning such materials, the students can learn the pronunciation and the intonation of the sentences. They can copy the utterances delivered by native speakers for daily conversation. It leads them to autonomy. Doing this kind of steps can develop their speaking skills inside and outside of the classroom. It enhances the students' competence to implement their speaking competence in daily life (Brown \& Yule, 2000).

After completing the treatment, the students joined the post-test. It is just an activity that the students did in the pre-test. They got the same questions as in the pre-test. The implementation of the post-test is to measure the progress of the students' skills in speaking by using a rubric. The scores they got in the post-test could be seen as follow:

Table 5. Post-test Scores

\begin{tabular}{lllll}
\hline No & Fluency & Intonation & Vocabulary & Average \\
\hline 1 & 82 & 83 & 82 & 82,3333 \\
2 & 84 & 83 & 85 & 84 \\
3 & 92 & 90 & 91 & 91 \\
4 & 81 & 80 & 82 & 81 \\
5 & 79 & 78 & 79 & 78,6667 \\
6 & 83 & 80 & 82 & 81,6667
\end{tabular}




\begin{tabular}{lllll}
\hline 7 & 85 & 83 & 85 & 84,3333 \\
8 & 86 & 86 & 87 & 86,3333 \\
9 & 88 & 86 & 90 & 88 \\
10 & 81 & 80 & 80 & 80,3333 \\
11 & 84 & 83 & 84 & 83,6667 \\
12 & 86 & 82 & 86 & 84,6667 \\
13 & 80 & 77 & 81 & 79,3333 \\
14 & 83 & 80 & 84 & 82,3333 \\
15 & 82 & 81 & 83 & 82 \\
16 & 84 & 82 & 83 & 83 \\
17 & 86 & 85 & 87 & 86 \\
18 & 81 & 80 & 82 & 81 \\
19 & 80 & 77 & 78 & 78,3333 \\
20 & 77 & 75 & 77 & 76,3333 \\
21 & 79 & 78 & 80 & 79 \\
22 & 83 & 80 & 86 & 83 \\
23 & 86 & 83 & 88 & 85,6667 \\
Average & 83,13043 & 81,3913 & 83,56522 & 82,69565 \\
\hline
\end{tabular}

From the scores above, it could be seen that all the students get the scores above 76 . Their average score from the three assessments is 83 . The students' average scores in fluency, intonation, and vocabulary are 83,81 , and 84 . It is categorized as good. It seems that the treatment which focuses on grammar usage supported by the adoption of comic strips and some reading materials affect their success in developing their speaking skills.

Indeed, their lowest average score is 76 and their highest one is 86 . Nobody got a bad score. On the other hand, there is a student got 75 in his intonation score. It is just one of the three assessments. His average score is 76 though. It is still categorized as good. It shows that nobody got a bad result by joining the treatment.

\section{Discussion \\ Before treatment}

The competence of the students in speaking skill is very low. It could be seen clearly in the chart below. Based on the rubric, by having such a kind of score, most of the students could not deliver their ideas to others properly. From the whole participants, there are only two who got 58 . The difference is only 8 scores with the lowest one. It means that all of them could not interact with other people in English.

\section{Chart 1. The Average of Pre-test Scores}

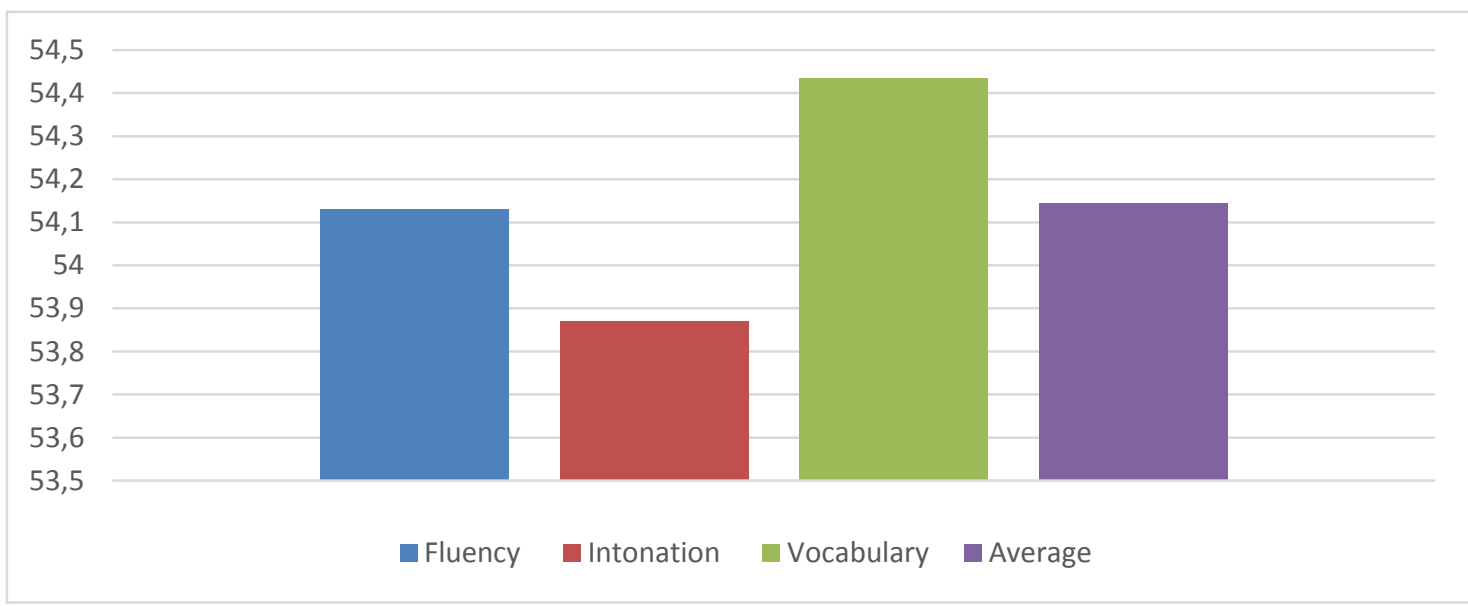


The lowest score is 53.9. It is in the skill of intonation practice. It is categorized as very bad. According to the rubric, it describes the students' competence in putting intonation in the proper place is very bad. It means that most of the students flattened the intonation of the utterances. The students did not know how to implement intonation on the words, phrases, and sentences.

On the other hand, the highest score is in vocabulary building. It is 54.4. it is also categorized as very bad. It is described as the very poor knowledge on choosing words in expressing the ideas. It means that most of the students are almost trapped in silence. They did not have a sufficient list of words in their head. It hampered them to deliver their ideas into utterances.

Another assessed competence is fluency. It describes the students' ability in conveying their intention properly. It includes grammar usage, speed, intonation, pronunciation, and choosing words. In these criteria, most of the students got 54.1. it is categorized as very bad. They almost uttered no words. They put a long pause to say one word or phrase to the other.

The overall of the competence in speaking, most of the students got 54.1. It means that the students' competence in delivering their intention in speaking is very bad. They need a method to improve their competence in speaking. They need to learn how to improve their vocabulary building, pronunciation, grammar usage, and some other skills which support speaking fluency.

\section{After treatment}

The treatment puts some benefits on the students to improve their competence in speaking practice. They did better than the one before joining the treatment. This kind of phenomenon could be seen clearly in the chart below:

Chart 2. The Average scores of Post-test

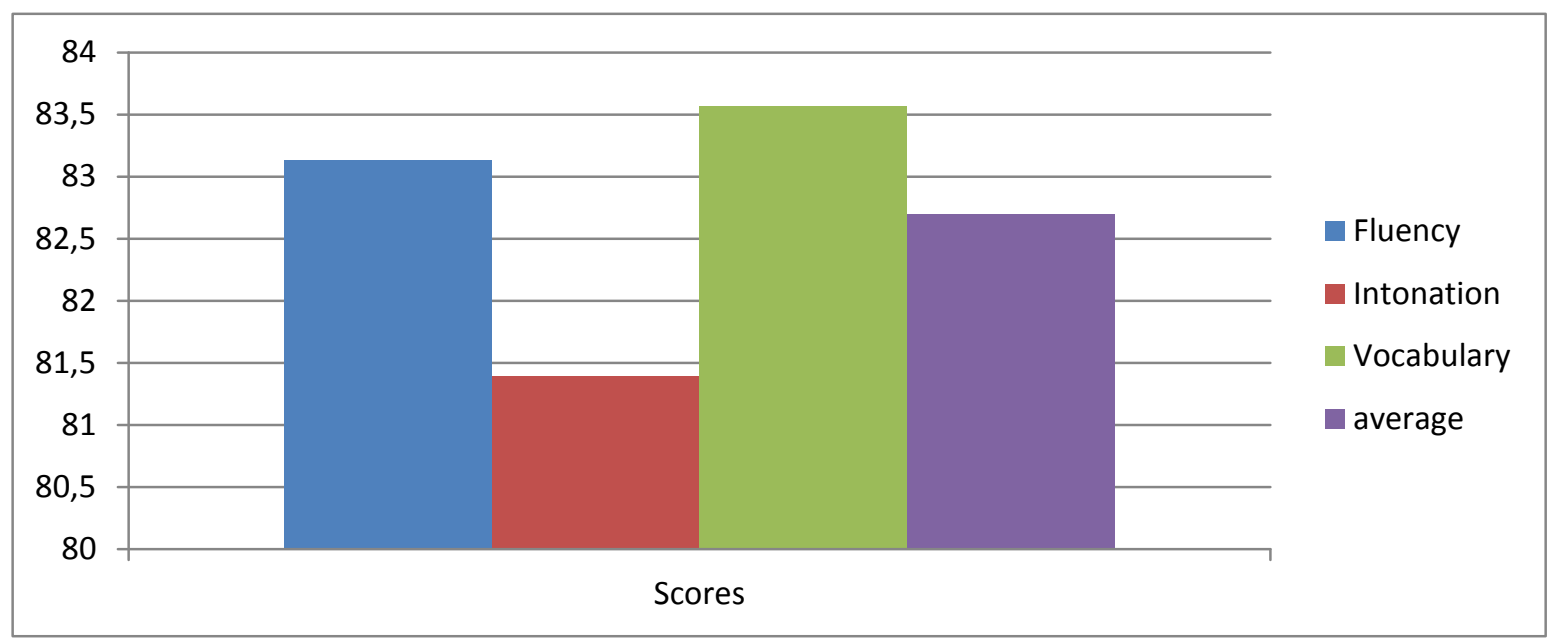

From the chart above is seen that most of the students got 83.1 in fluency point. It is categorized as good. It seems that the drilling on grammar usage by using GTM, vocabulary building by using reading text and scripts, listening skills by using the recording, and speaking skill by using comic strips develop the students' fluency in practicing speaking. The 18 opportunities had built the students' competence in speaking. Based on the rubric, the good category in fluency means that most of the students are able to deliver ideas with the proper sentence building, to choose words, and to adapt the proper intonation.

For the second point, it is intonation. Most of the students got 81.3. it is categorized as good. To gain such progress, the students had used the recording of the native utterances while reading text and scripts. It seems that the sample of speaking delivered by the native speakers influences the students' ability to adapt the proper intonation. Based on the rubric, the good category means that the students are able to put the right intonation in the proper place but sometimes fall into the flat. They still need some more occasions to improve their intonation adaptation. 
Furthermore, on the last point, it is the vocabulary building. Most of the students got 83.6. this kind of score is categorized as good. The students had tried so well in gaining such an achievement. To get that ability, the students had learned reading text and scripts on some occasions. They used their electronic dictionary to understand unfamiliar words. This kind of activity develops their vocabulary list in their head. A good category in vocabulary building, according to the rubric, means that the students are able to express an understandable opinion.

The overall of treatment results good category. It is shown in the chart above. In the chart, it said that the students' average score in speaking competence is 82.7 . It means that most of the students are good at choosing words, adapting intonation, and speaking fluency. The good category is a kind of achievement that needs to be developed for another opportunity to get the optimum result.

\section{Result}

\section{The Progress}

The whole activity could be dragged a comparison between the pre-test and post-test. The chart below tells about the average scores the students got in pre-test and post-test. By watching the chart, it could be seen as a big leap of progress. The progress is around 28.5 points. Based on the rubric, the students had turned their competence in speaking skills from very bad to good.

Chart 3. The average scores of pre-test andpost-test

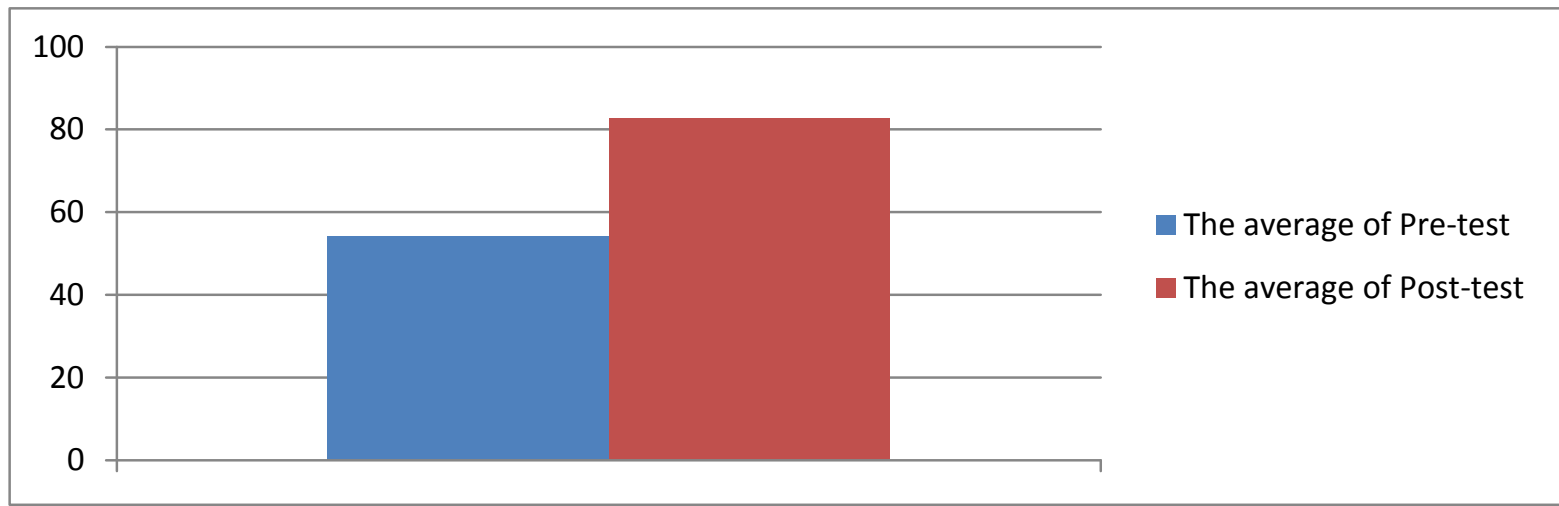

From the chart above it could be seen the progress of the students' competence in speaking is great. It seems that the use of media like comic strips to enhance the fluency of speaking is very important. The use of such a media was supported by using Grammar review, reading text and scripts, listening to the recording, and using the electronic dictionary to gain desirable speaking competence.

Nevertheless, this kind of findings is very useful for the teacher to implement it inside or outside of the classroom as an alternative method to teach speaking for EFL young learners. It will support the implementation of using technology 4.0 in the teaching-learning process. Moreover, the result of this research needs to be developed for some further in another opportunity of similar research to gain a better result.

\section{CONCLUSION}

The fifth graders have learned English for 5 years. Their learning is starting in the first grade to the fifth. But, they still got difficulties to deliver their ideas in speaking. Their competence in speaking is categorized very badly. It seems that they need to improve their competence in speaking as English learners. By joining the 18 opportunities for treatment, the students could improve their speaking competence from very bad to good category. It seems that the progress of the speaking competence could be gained by adapting GTM and comic strips supported by reading text and script, listening to the recording, and using an electronic dictionary.

\section{REFERENCES}

Aqel. I. M. (2013). The Effect of Using Grammar-Translation Method on Acquiring English As 
A Foreign Language. International Journal Of Asian Social Science, 3(12): 2469-2476. Derived From Http:/Www.Aessweb.Com/Pdf-Files/ljass-3(12)-2469-2476.Pdf

Brown, G. \& Yule, G. (2000). Teaching Spoken Language: Approach based on the Analysis of Conversational English. Cambridge: Cambridge University Press.

Brown, H.D. (2001). Teaching by Principles: An Interactive Approach to Language Pedagogy. Singapore: Longman.

Copland. F, and Garton. S. (2014). Key Themes And Future Directions In Teaching English To Young Learners: Introduction To The Special Issue. Elt Journal, Volume 68, Issue 3, July 2014, Taken From Pages 223-230,Https://Doi.Org/10.1093/Elt/Ccu030

Derrick, J. (2008). Using Comics With Esl/Efl Students. The Internet Tes/ Journal, Vol. xiv, No. 7. Taken From Http://lteslj.Org/Techniques/Derrick-Usingcomics.Html

Harmer, J. (2001). The Practice of English Language Teaching (third ed.). New York: Longman.

Harmer, J. (2007). How to Teach English, Seventh Impression. London: Longman.

Heaton, J. B. (2004). Writing English Language Tests. New York: Oxford University Press.

Huang, I. Y. (2008). Role Play For Esl/Efl Children in The English Classroom. The Internet Tesl Journal, Vol. xiv, No. 2, February 2008. Taken From Http://lteslj.Org/Techniques/Huang-Roleplay.Html

Kaharuddin. (2018). The Communicative Grammar Translation Method: A Practical Method To Teach Communication Skills Of English. Eternal, Volume 4, Number 2. Derived From Http://Journal.Uin-Alauddin.Ac.Id/Index.Php/Eternal/Article/View/6292

Moon, J. (2000). Children Learning English. Oxford: Macmillan Heinemann.

Prawerti, R. C. (2015). The effectiveness of Using Strip Stories Technique in Teaching Speaking toward Students' Speaking Achievement. Universum Jurnal Kelslaman dan Kebudayaan, 9(2), 255-264. Derived from https://jurnal.iainkediri.ac.id/index.php/universum/article/view/91

Rabab'ah,G. (2005). Communication Problems Facing Arab Learners of English. Journal of Language And Learning, 3(1),Issn 1740-4983.

Richards, J., Platt, J. \& Weber, H. (1985). Longman Dictionary of Applied Linguistics. London: Longman.

Richards, J., \& Renandya, W. (2005). Communicative Language Teaching Today. RELCP. Singapore: SEAMEO Regional Language Center.

Saville-Troike, M. S. (2006). Introducing Second Language Acquisition. New York: Cambridge University Press

Setyaningsih, A. (2007). Teachlng English To Young Learners Through Songs. Journal Ofenglish And Education, Vol. 1, No. 2. Derived From Https://Journal.Uii.Ac.Id/Jee/Article/View/6443

Sysoyev, P. V. (1999). Integrative L2 Grammar Teaching: Exploration, Explanation And Expression. The Internet Tesl Journal, Vol. v, No. 6, June 1999. Taken From Http://Iteslj.Org/Articles/Sysoyev-Integrative.Html 